\title{
Penerapan Metode AHP dan COPRAS-G untuk Menentukan Prioritas Perbaikan Drainase Pada Jalan Nasional Di Kota Bandung
}

\author{
Mahmud Imrona $^{\# 1}$, Aditya Arif Budiutama ${ }^{\# 2}$, Eko Darwiyanto ${ }^{\# 3}$, Dini Handayani ${ }^{\# 4}$ \\ \# School of Computing, Telkom University \\ Jl. Telekomunikasi No. 1, Ters. Buah Batu Bandung 40257 Indonesia \\ ${ }^{1}$ mahmudimrona@telkomuniversity.ac.id \\ 2adityaabu@students.telkomuniversity.ac.id \\ ${ }^{3}$ ekodarwiyanto@,telkomuniversity.ac.id \\ ${ }^{4}$ dini.handayani@pusjatan.pu.go.id
}

\begin{abstract}
Drainage is one of the road's complementary building that works for reduce and dispose excess water from one region or area, so that region can be functioned optimally . But if there is damage to drainage will lead to disasters such as flood that can lead to damage to road structures, so it needs maintenance so that drainage works properly. However, infrastructure maintenance is calculated by the amount of funds, time and resources. Such limitations result in inequalities in decision-making in prioritizing drainage improvements. To determine the priority of the improvement used Analytic Hierarchy Process (AHP) to calculate the weight of each criterion, Complex Proportional Assessment of Alternatives with Grey Relations (COPRAS-G) method to get priority order to drainage maintenance and Mean Absolute Error (MAE) method to get the accuracy value. From the research results obtained the weight of the importance of each criterion, drainage damage with a weight of 0.71 , volume of drainage damage with a weight of 0.20 and the third criteria is repair time of drainage with a weight of 0.09 . With the value of CR is 0.083 indicates that criteria matrix are consistent. The accuracy result from comparison of improvement priority from PPK PJN Metropolitan Bandung and COPRAS-G is $100 \%$. The case study is the Soekarno-Hatta road in Bandung City.
\end{abstract}

Keywords: AHP, COPRAS-G, drainage maintenance, MAE, priority

\section{Abstrak}

Drainase merupakan salah satu bangunan pelengkap jalan berfungsi untuk mengurangi dan membuang kelebihan air dari suatu kawasan atau lahan, sehingga lahan dapat difungsikan secara optimal. Namun apabila terjadi kerusakan pada drainase maka kerusakan tersebut dapat menyebabkan bencana seperti banjir yang dapat mengakibatkan rusaknya struktur jalan, sehingga diperlukan pemeliharaan agar drainase tetap dapat berfungsi dengan baik. Namun pemeliharaan infrastruktur dibatasi oleh jumlah dana, waktu dan sumber daya. Keterbatasan tersebut mengakibatkan ketimpangan pengambilan keputusan dalam penentuan prioritas perbaikan drainase. Untuk menentukan prioritas perbaikan tersebut digunakan metode Analytic Hierarchy Process (AHP) untuk menghitung bobot setiap kriteria, metode COmplex PRoportional ASsessment of alternatives with Grey relations (COPRAS-G) untuk mendapatkan urutan prioritas perbaikan drinase dan metode Mean Absolute Error (MAE) untuk mendapatkan nilai akurasi. Dari hasil penelitian diperoleh bobot setiap kriteria, kriteria pertama adalah 
Mahmud ImRONA ET.AL.

Tingkat Kerusakan Drainase dengan bobot 0,71, Volume Kerusakan Drainase dengan bobot 0,20 dan kriteria ketiga Waktu Perbaikan Drainase dengan bobot 0,09. Dengan nilai CR 0,083 menunjukkan bahwa matriks kriteria adalah konsisten. Hasil akurasi dari perbandingan prioritas perbaikan drainase antara PPK PJN Metropolitan Bandung dan COPRAS-G sebesar 100\%. Studi kasus jalan Soekarno-Hatta di kota Bandung.

Kata Kunci: AHP, COPRAS-G, MAE, perbaikan drainase, prioritas, perbaikan drainase

\section{INTRODUCTION}

D ainase merupakan saluran air di permukaan atau di bawah tanah, baik yang terbentuk secara alami maupun dibuat oleh manusia. Drainase merupakan salah satu bangunan pelengkap jalan yang berfungsi untuk mengatur dan mengendalikan sistem aliran air hujan agar aman dan mudah melewati jalan, belokan daerah curam. Bangunan drainase contohnya seperti selokan dan gorong-gorong. Tidak dapat dipungkiri dengan semakin tingginya pertumbuhan suatu daerah maka lahan terbuka hijau akan semakin berkurang karena beralih fungsi, hal ini dapat menyebabkan berkurangnya daerah resapan air hujan sehingga air hujan yang tidak terserap ke dalam tanah akan mengalir menuju drainase, namun apabila volume air tersebut melebihi kapasitas drainase maka air akan meluap dan menyebabkan banjir. Apabila terjadi banjir yang cukup lama banjir tersebut dapat merusak jalan maupun drainase itu sendiri. Maka dibutuhkan pemeliharaan apabila terjadi kerusakan pada drainase, namun apabila terdapat banyak kerusakan drainase di daerah yang berbeda dan pemeliharaan tersebut dibatasi oleh jumlah dana, waktu dan sumber daya. Hal tersebut dapat mengakibatkan ketimpangan pengambilan keputusan dalam penentuan prioritas perbaikan drainase. Maka dibutuhkan suatu sistem yang menentukan prioritas perbaikan drainase yang terbaik. Pada penelitian ini drainase di jalan nasional soekarnohatta kota Bandung dipilih sebagai studi kasus. Pada penelitian sebelumnya menentukan Jalan Hutan berdasarkan metode AHP dan COPRAS-G di Iran [1]. Merujuk [1] penelitian ini membahas tentang prioritas perbaikan drainase dengan menggunakan metode AHP dan COPRAS-G di jalan nasional di kota Bandung. Metode AHP digunakan untuk menentukan bobot masing-masing kriteria, yaitu tingkat kerusakan drainase, volume kerusakan drainase dan waktu perbaikan drainase. Metode COPRAS-G digunakan untuk mendapatkan rangking prioritas untuk setiap area kerusakan drainase dimana rangking prioritas tersebut akan dibandingkan dengan peringkat prioritas dari PPK PJN Metropolitan Bandung menggunakan metode Mean Absolute Error (MAE) untuk mendapatkan nilai akurasinya. Penelitian ini memberikan urutan prioritas perbaikan drainase yang dapat digunakan oleh PPK PJN Metropolitan Bandung.

\section{STUDI LITERATUR}

The aim of a literature review is to show the readers that authors have read, and have a good grasp of, the main published work concerning a particular topic or question in the field. It is very important to note that the review should not be simply a description of what others have published in the form of a set of summaries, but should take the form of a critical discussion, showing insight and an awareness of differing arguments, theories and approaches. It should be a synthesis and analysis of the relevant published work, linked at all times to your own purpose and rationale.

A. Kriteria Penilaian

1. Tingkat Kerusakan Drainase

Didasarkan Peraturan Menteri Pekerjaan Umum no: 13 /PRT/M/2011 tentang tata cara pemeliharaan dan penilikan jalan, penilaian tingkat kerusakan [2] dapat mengacu pada Tabel 1.

Tabel 1 Nilai Tingkat Kerusakan Drainase

\begin{tabular}{|c|c|l|}
\hline Nilai & Kerusakan & \multicolumn{1}{c|}{ Keterangan } \\
\hline 0 & $0 \%$ & Drainase baru dan tanpa kerusakan \\
\hline 1 & $1-20 \%$ & Kerusakan Kecil \\
\hline 2 & $21-40 \%$ & Kerusakan yang memerlukan pemantauan atau pemeliharaan diwaktu mendatang \\
\hline
\end{tabular}




\begin{tabular}{|c|c|l|}
\hline Nilai & Kerusakan & \multicolumn{1}{c|}{ Keterangan } \\
\hline 3 & $41-60 \%$ & Kerusakan yang memerlukan tindakan secepatnya \\
\hline 4 & $61-80 \%$ & Kondisi Kritis \\
\hline 5 & $81-100 \%$ & Drainase tidak berfungsi \\
\hline
\end{tabular}

2. Volume Kerusakan Drainase

Mengacu pada lampiran III Peraturan Menteri Pekerjaan Umum no : 12/PRT/M/2014 tentang Tata Cara Operasi dan Pemeliharaan Sistem Drainase Perkotaan, volume kerusakan drainase adalah pengukuran profil memanjang dan melintang untuk mengetahui volume kerusakan drainase [3].

3. Waktu Perbaikan Drainase

Dari kuesioner didapat bahwa waktu pengerjaan termasuk kriteria dalam menentukan prioritas perbaikan drainase. Waktu pengerjaan drainase ditentukan oleh Dinas PU, Kontraktor dan Konsultan

B. Metode yang Digunakan

1. Analytical Hierarchy Process (AHP)

Analytical Hierarchy Process (AHP) merupakan salah satu sistem pendukung keputusan yang dikembangkan oleh seorang ahli matematika bernama Thomas L. Saaty pada awal tahun 1970-an. AHP adalah teori pengukuran melalui perbandingan berpasangan dan bergantung pada penilaian para ahli untuk mendapatkan skala prioritas [4]. Beberapa penerapan metode AHP [1] [4] [5] [6].

Langkah-langkah dalam metode AHP sebagai berikut [7]:

1) Mengidentifikasi permasalahan dan menentukan solusi yang diinginkan.

2) Menyusun Hirarki dalam permasalahan yang dihadapi.

3) Menyusun Kriteria pendukung dan membentuk matriks berpasangan yang diisi menggunakan bilangan skala Saaty $\{1 / 9,1 / 8,1 / 7,1 / 6,1 / 5,1 / 4,1 / 3,1 / 2,1,2,3,4,5,6,7,8,9\}$ untuk menyatakan kepentingan relatif dari suatu Kriteria terhadap Kriteria lainnya. Dimana 9 menyatakan lebih penting sangat mutlak, sedangkan $1 / 9$ berarti sangat tidak mutlak pentingnya, serta 1 menyatakan sama penting [4].

Bentuk Matriks berpasangan berbentuk seperti (1).

$$
D=\left[\begin{array}{cccc}
1 & d_{12} & \ldots & d_{1 n} \\
\frac{1}{d_{12}} & 1 & \ldots & d_{2 n} \\
\vdots & \vdots & & \\
\frac{1}{d_{1 n}} & \frac{1}{d_{2 n}} & \ldots & \vdots
\end{array}\right], d_{i j}=1, d_{i j}=\frac{1}{d_{i j}} \neq 0
$$

4) Normalisasi matriks keputusan berpasangan.

Bagilah setiap entri dengan nilai jumlah entri pada setiap kolom yang berkaitan.

5) Menghitung nilai priority vector.

Hitung nilai rata-rata setiap baris pada matriks ternormalisasi, maka didapat nilai priority vector untuk setiap kriteria.

6) Menghitung nilai eigen terbesar $\lambda_{\max }$.

a. Kalikan matriks berpasangan dengan priority vector maka didapatkan nilai weighted sum.

b. Bagilah weighted sum dengan priority vector kemudian dibagi jumlah kriteria untuk mendapatkan nilai $\lambda_{\max }$.

7) Menghitung Consistency Index (CI).

Dimana $k$ adalah banyaknya kriteria.

$$
C I=\frac{\lambda_{\max }-k}{k-1}
$$

8) Menghitung Consistency Ratio (CR).

$$
C R=\frac{C I}{R I}
$$

Penentuan nilai Random Index (RI) [4] mengacu pada Tabel 2. 


\begin{tabular}{|c|c|c|c|c|c|c|c|c|c|c|}
\hline$n$ & 1 & 2 & 3 & 4 & 5 & 6 & 7 & 8 & 9 & 10 \\
\hline RI & 0.00 & 0.00 & 0.58 & 0.9 & 1.12 & 1.24 & 1.32 & 1.41 & 1.45 & 1.49 \\
\hline
\end{tabular}

2. Complex Proportional Assessment of Alternatives with Grey relations (COPRAS-G)

Pada tahun 2008 Zavadskas mengembangkan metode COPRAS-G [8] dengan penerapan dari Grey system theory [9] yang dikembangkan oleh Deng pada tahun 1982. COPRAS-G dapat digunakan untuk menentukan peringkat alternatif dimana nilai yang digunakan dinyatakan dalam interval didasarkan pada kondisi sebenarnya dalam pengambilan keputusan. Beberapa penerapan metode COPRAS-G [1] [6]. Langkah-langkah dalam metode Copras-G sebagai berikut [10]:

1) Memilih seperangkat kriteria yang paling penting dan alternatif.

2) Membuat matriks keputusan $Y$.

$$
Y=\left[\begin{array}{cccc}
{\left[y_{11}\right]} & {\left[y_{12}\right]} & \cdots & {\left[y_{2 m}\right]} \\
{\left[y_{21}\right]} & {\left[y_{22}\right]} & \cdots & {\left[y_{2 m}\right]} \\
\vdots & \vdots & & \vdots \\
{\left[y_{n 1}\right]} & {\left[y_{n 2}\right]} & \cdots & {\left[y_{n m}\right]}
\end{array}\right]=\left[\begin{array}{cccc}
{\left[\underline{y}_{11} ; \bar{y}_{11}\right]} & {\left[\underline{y}_{12} ; \bar{y}_{12}\right]} & \cdots & {\left[\underline{y}_{2 m} ; \bar{y}_{2 m}\right]} \\
{\left[\underline{y}_{21} ; \bar{y}_{21}\right]} & {\left[\underline{y}_{22} ; \bar{y}_{22}\right]} & \cdots & {\left[\underline{y}_{2 m} ; \bar{y}_{2 m}\right]} \\
\vdots & \vdots & & \vdots \\
{\left[\underline{y}_{n 1} ; \bar{y}_{n 1}\right]} & {\left[\underline{y}_{n 2} ; \bar{y}_{n 2}\right]} & \cdots & {\left[\underline{y}_{n m} ; \bar{y}_{n m}\right.}
\end{array}\right]
$$

Dengan $y_{i j}$ ditentukan $y_{i j}$ (nilai terkecil, batas bawah) dan $\bar{y}_{i j}$ (nilai terbesar, batas atas)

3) Menentukan bobot kriteria $k_{j}$, pada penelitian ini bobot yang digunakan adalah bobot yang didapatkan dari proses AHP.

4) Normalisasi matriks kepurusan $Y$ dihitung dengan persamaan.

$$
\begin{aligned}
& \widetilde{\widetilde{y_{l j}}}=\frac{\underline{y_{i j}}}{\frac{1}{2}\left(\sum_{i=1}^{n} \underline{y_{i j}}+\sum_{i=1}^{n} \overline{y_{i j}}\right)}=\frac{2 y_{i j}}{\left(\sum_{i=1}^{n} \underline{y_{i j}}+\sum_{i=1}^{n} \overline{y_{i j}}\right)}
\end{aligned}
$$

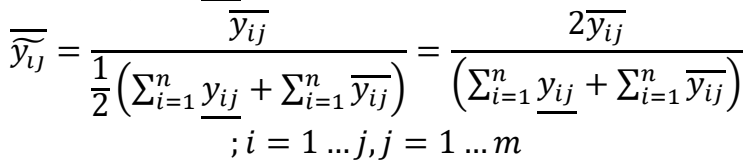

Pada persamaan (5) $\underline{y}_{i j}$ adalah nilai terendah dari kriteria $j$ di alternatif $i$ dari solusi. $\bar{y}_{i j}$ adalah nilai tertinggi dari kriteria $j$ di alternatif $i$ dari solusi. $n$ adalah jumlah kriteria dan $m$ adalah jumlah alternatif yang dibandingkan. Kemudian, matriks pengambilan keputusan dinormalisasi. Dengan persamaan (6) :

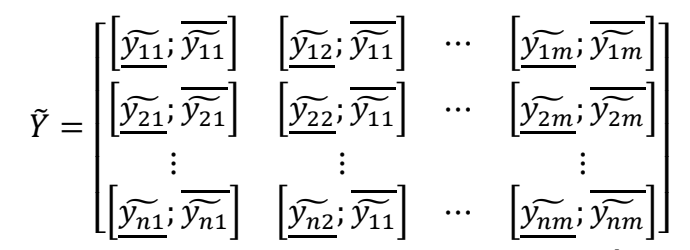

5) Menghitung matriks keputusan ternormalisasi diboboti $\hat{Y}$. Nilai normalisasi terboboti dihitung $\hat{y}_{i j}$ sebagai berikut :

$$
\hat{y}_{i j}=\tilde{y}_{i j} \times k_{j} \text {; atau } \hat{\hat{y}}_{i j}=\tilde{y}_{i j} \times k_{j} \text { dan } \hat{\bar{y}}_{i j}=\tilde{\bar{y}}_{i j} \times k_{j}
$$

Dimana $k_{j}$ adalah bobot kriteria j. Maka matriks pengambilan keputusan yang ternormalisasi (8). 


$$
\hat{Y}=\left[\begin{array}{cccc}
{\left[\hat{y}_{11}\right]} & {\left[\hat{y}_{12}\right]} & \cdots & {\left[\hat{y}_{1 m}\right]} \\
{\left[\hat{y}_{21}\right]} & {\left[\hat{y}_{22}\right]} & \cdots & {\left[\hat{y}_{2 m}\right]} \\
\vdots & \vdots & & \vdots \\
{\left[\hat{y}_{n 1}\right]} & {\left[\hat{y}_{n 2}\right]} & \cdots & {\left[\hat{y}_{n m}\right]}
\end{array}\right]=\left[\begin{array}{cccc}
{\left[\hat{y}_{11} ; \overline{\hat{y}}_{11}\right]} & {\left[\hat{y}_{12} ; \hat{\bar{y}}_{12}\right]} & \cdots & {\left[\hat{y}_{2 m} ; \hat{\bar{y}}_{2 m}\right]} \\
{\left[\hat{y}_{21} ; \hat{\bar{y}}_{21}\right]} & {\left[\hat{y}_{22} ; \hat{\bar{y}}_{22}\right]} & \cdots & {\left[\hat{y}_{2 m} ; \overline{\hat{y}}_{2 m}\right]} \\
\vdots & \vdots & & \vdots \\
{\left[\hat{y}_{n 1} ; \overline{\hat{y}}_{n 1}\right]} & {\left[\hat{y}_{n 2} ; \hat{\hat{y}}_{n 2}\right]} & \cdots & {\left[\hat{y}_{n m} ; \overline{\hat{y}}_{n m}\right.}
\end{array}\right]
$$

6) Menghitung jumlah $B_{i}$ dari kriteria yang lebih besar.

$$
B_{i}=\frac{1}{2} \sum_{j=1}^{m}\left(\underline{\widehat{y_{l \jmath}}}+\widehat{\widehat{y_{l \jmath}}}\right)
$$

7) Menghitung jumlah $C_{i}$ dari kriteria yang lebih kecil.

$$
C_{i}=\frac{1}{2} \sum_{j=k+1}^{m}\left(\underline{\widehat{y_{l j}}}+\overline{\widehat{y_{l j}}}\right), j=k \ldots m
$$

Di persamaan (2-11), (m-k) adalah jumlah kriteria pilihan dengan nilai minimum.

8) Menentukan nilai $C_{\min }$ (nilai minimal dari $C_{i}$ ).

$$
C_{\text {min }}={ }_{i}^{\min } C_{i}, i=1 \ldots n
$$

9) Menghitung signifikansi relatif dari setiap alternatif $A_{i}$.

$$
A_{i}=B_{i}+\frac{\sum_{i=1}^{n} C_{i}}{C_{i} \sum_{i=1}^{n} \frac{1}{C_{i}}}
$$

10) Menentukan kriteria optimal $\left(\mathrm{O}_{\mathrm{p}}\right)$.

$$
O_{p}=\max _{i} A_{i}, i=1 \ldots n
$$

11) Menentukan urutan prioritas alternatif.

12) Menghitung derajat utilitas $U_{i}$ untuk setiap alternative.

$$
U_{i}=\frac{A_{i}}{O_{p}} 100 \%
$$

Dimana $A_{i}$ dan $O_{p}$ adalah signifikasi relatif, diperoleh dengan persamaan (12).

3. Mean Absolute Error (MAE)

Mean Absolute Error (MAE) digunakan untuk menghitung kesalahan dari prediksi sistem dengan hasil yang sebenarnya tanpa menghiraukan tanda positif atau negatif. Persamaan menghitung MAE dinyatakan dalam [11] dalam persamaan (15).

$$
M A E=\sum_{i=1}^{n} \frac{|f i-y i|}{f i}
$$

Dengan $f i$ adalah prediksi dari sebenarnya dan $y i$ adalah hasil prediksi.

$$
\text { Akurasi }=1-M A E
$$

\section{RESEARCH METHOD}

A. Perancangan Sistem

Alur perancangan sistem untuk menentukan prioritas perbaikan drainase menggunakan metode AHP dan COPRAS-G digambarkan pada Gambar 1. 


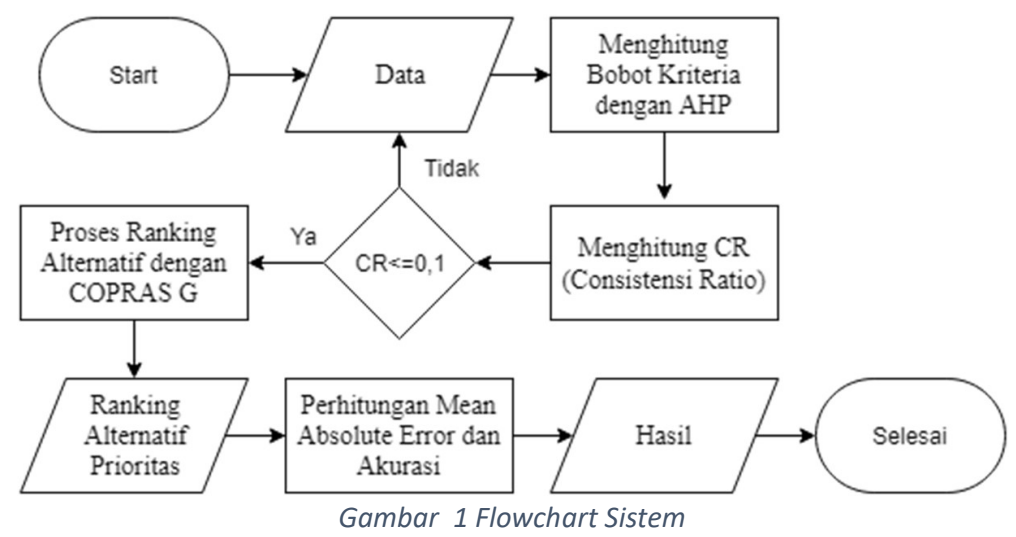

B. Data Set

1. Data Kerusakan Drainase

Data kerusakan drainase yang dalam kasus studi ini adalah ruas jalan Soekarno-Hatta di kota Bandung. Data ini berisi nama ruas jalan, tingkat kerusakan drainase, jumlah volume kerusakan drainase pada tiap ruas jalan, waktu pengerjaan perbaikan drainase dan urutan prioritas perbaikan menurut PKK PJN Metropolitan Bandung, lihat Tabel 3. Data kerusakan drainase terdiri atas 9 set data dimana 3 set data dengan 3 titik kerusakan drainase, 2 set data dengan 4 titik kerusakan drainase, 2 set data dengan 5 titik kerusakan drainase dan 2 set data dengan 10 titik kerusakan drainase. Jumlah titik kerusakan drainase yang berbeda pada setiap data set kerusakan drainase digunakan untuk melihat apakah dengan jumlah titik kerusakan drainase yang berbeda akan berpengaruh pada hasil akurasi dari setiap set data kerusakaan drainase.

Tabel 3 Sample Data Kerusakan Darinase Ruas Jalan Soekarno-Hatta Kota Bandung

\begin{tabular}{|c|c|c|c|c|c|c|c|c|c|}
\hline \multirow{2}{*}{$\begin{array}{c}\text { Kasus } \\
\text { Uji }\end{array}$} & \multirow{2}{*}{ No } & \multirow{2}{*}{ Ruas Jalan } & \multicolumn{2}{|c|}{ Lokasi } & \multirow{2}{*}{\multicolumn{2}{|c|}{$\begin{array}{c}\begin{array}{c}\text { Tingkat } \\
\text { Kerusakan }\end{array} \\
\%\end{array}$}} & \multirow{2}{*}{$\begin{array}{l}\text { Volume } \\
\text { Kerusakan }\end{array}$} & \multirow{2}{*}{$\begin{array}{c}\begin{array}{c}\text { Waktu } \\
\text { Perbaikan }\end{array} \\
\text { (Hari) }\end{array}$} & \multirow{2}{*}{$\begin{array}{c}\text { Index } \\
\text { Kerusakan } \\
\text { dari PPK PJN }\end{array}$} \\
\hline & & & $\mathrm{Km}$ & $\mathrm{Km}$ & & & & & \\
\hline \multirow{3}{*}{ A } & 1 & Soekarno-Hatta & $9+700$ & $9+800$ & 1 & 20 & 80 & 8 & 3 \\
\hline & 2 & Soekarno-Hatta & $11+100$ & $11+200$ & 21 & 40 & 90 & 9 & 2 \\
\hline & 3 & Soekarno-Hatta & $12+300$ & $12+350$ & 41 & 60 & 40 & 4 & 1 \\
\hline \multirow{3}{*}{ B } & 1 & Soekarno-Hatta & $9+700$ & $9+800$ & 21 & 21 & 70 & 7 & 3 \\
\hline & 2 & Soekarno-Hatta & $11+100$ & $11+200$ & 21 & 40 & 80 & 8 & 2 \\
\hline & 3 & Soekarno-Hatta & $12+300$ & $12+350$ & 41 & 60 & 50 & 5 & 1 \\
\hline
\end{tabular}

\section{Data Kuesioner}

Data kuesioner diperoleh dari pengisian kuesioner oleh Kepala Pengawas Lapangan PKK1 PJN Metropolitan Bandung terkait dengan perbaikan drainase di kota Bandung. Data kuesioner digunakan pada proses AHP untuk menentukan bobot setiap kriteria dengan menggunakan skala perbandingan berpasangan yang berbentuk Tabel .

C. Hitung Bobot Kriteria dengan AHP

Menggunakan langkah-langkah pada metode AHP sebagaimana dinyatakan dalam [7].

D. Hitung Nilai Setiap Alternatif Titik Kerusakan Drainase dengan Menggunakan AHP dan COPRAS-G Setelah mendapatkan bobot setiap kriteria, lakukan prosedur COPRAS-G sebagaimana [10]. Sampai didapat derajat utilitas $U_{i}$ untuk setiap alternatif dengan persamaan (14). 
E. Tentukan prioritas setiap alternatif titik kerusakan

Setelah menghitung derajat utilitas dari setiap alternatif $U_{i}$ maka dapat dilakukan penentuan prioritas dengan mengurutkan nilai $U_{i}$ dari yang terbesar ke yang terkecil. Semakin besar nilai $U_{i}$ maka semakin tinggi tingkat prioritas perbaikan pada drainase tersebut.

F. Menghitung Mean Absolute Error (MAE)

Hasil prioritas perbaikan drainase menggunakan AHP dan COPRAS-G dibandingkan dengan prioritas perbaikan drainase dari PPK PJN Metropolitan Bandung untuk mendapatkan nilai MAE (15) dan (16) untuk menghitung nilai akurasi.

\section{RESUltS AND DisCUSSION}

Tabel 4 Hasil Kuisioner Tingkat Kepentingan antar Kriteria

\begin{tabular}{|c|c|c|c|c|c|c|c|c|c|c|c|c|c|c|c|c|c|c|}
\hline \multirow{2}{*}{ Kriteria A } & \multicolumn{10}{|c|}{ Skala } & \multirow{2}{*}{ Kriteria B } \\
\cline { 2 - 10 } & 9 & 8 & 7 & 6 & 5 & 4 & 3 & 2 & 1 & 2 & 3 & 4 & 5 & 6 & 7 & 8 & 9 & \\
\hline Tingkat kerusakan & & & & & $\mathrm{v}$ & & & & & & & & & & & & & Volume kerusakan \\
\hline Tingkat kerusakan & & & & $\mathrm{v}$ & & & & & & & & & & & & & & Waktu pengerjaan \\
\hline Volume kerusakan & & & & & & & $\mathrm{v}$ & & & & & & & & & & & Waktu pengerjaan \\
\hline
\end{tabular}

Dari skala kepentingan antar kriteria di Table 4 dapat diperoleh matriks perbandingan berpasangan dengan membandingkan tingkat kepentingan setiap kriteria denga kriteria lainya. Misalkan membandingkan kriteria tingkat kerusakan dengan kriteria volume kerusakan, dari Table 4 dapat dilihat bahwa nilai inensitas kepetingan lebih memihak 5 poin pada tingkat kerusakan yang artinya tingkat kerusakan lebih penting daripada volume kerusakan. Begitupun dengan kriteria yang lain semuanya dibandingkan sehingga didapatkan matrik perbandingan berpasangan di Tabel 5 .

Tabel 5 Hasil Bobot Kriteria dengan Metode AHP

\begin{tabular}{|c|c|c|c|c|}
\hline Kriteria & Tingkat Kerusakan & Volume Kerusakan & Waktu Perbaikan & Bobot \\
\hline Tingkat Kerusakan & 1 & 5 & 6 & 0,71 \\
\hline Volume Kerusakan & $1 / 5$ & 1 & 3 & 0,20 \\
\hline Waktu Perbaikan & $1 / 6$ & $1 / 3$ & 1 & 0,09 \\
\hline & $\mathrm{CI}=0,048$ & $\mathrm{RI}(\mathrm{n}=3)=0,58$ & $\mathrm{CR}=\mathrm{CI} / \mathrm{RI}=0,083$ & \\
\hline
\end{tabular}

Dengan menggunakan AHP diperoleh bobot masing-masing kriteria, yaitu tingkat kerusakan drainase dengan bobot 0,71 , volume kerusakan drainase dengan bobot 0,20 dan waktu pengerjaan drainase dengan bobot 0,9 sebagaimana dinyatakan dalam Table 5. Dengan nilai CR 0,083 dimana nilai CR yang di dapat kurang dari 0,1 yang menunjukan bahwa penilaian bobot kepentingan antara kriteria tersebut bersifat konsisten.

Tabel 6 Hasil Prioritas menggunakan AHP dan COPRAS-G, nilai MAE dan Nilai Akurasi

\begin{tabular}{|c|c|c|c|c|c|c|c|c|c|}
\hline $\begin{array}{c}\text { Uji } \\
\text { Kasus }\end{array}$ & $\begin{array}{c}\text { Ruas Jalan } \\
\text { (Region) }\end{array}$ & $B_{I}$ & $C_{I}$ & $A_{I}$ & $\begin{array}{c}U_{I} \\
(\%)\end{array}$ & $\begin{array}{c}\text { Prioritas COPRAS-G } \\
(f i)\end{array}$ & $\begin{array}{c}\text { Prioritas PKK PJN } \\
(y i)\end{array}$ & $\begin{array}{l}\text { MAE } \\
(\%)\end{array}$ & $\begin{array}{c}\text { Akurasi } \\
(\%)\end{array}$ \\
\hline \multirow{3}{*}{ A } & $\mathrm{A} 1$ & 0,16 & 0,03 & 0,18 & 38,60 & 3 & 3 & \multirow{3}{*}{0} & \multirow{3}{*}{100} \\
\hline & $\mathrm{A} 2$ & 0,32 & 0,04 & 0,34 & 72,76 & 2 & 2 & & \\
\hline & A3 & 0,43 & 0,02 & 0,47 & 100 & 1 & 1 & & \\
\hline \multirow{3}{*}{ B } & $\mathrm{B} 1$ & 0,15 & 0,03 & 0,18 & 37,63 & 3 & 3 & \multirow{3}{*}{0} & \multirow{3}{*}{100} \\
\hline & B2 & 0,32 & 0,04 & 0,34 & 71,37 & 2 & 2 & & \\
\hline & B3 & 0,44 & 0,02 & 0,48 & 100 & 1 & 1 & & \\
\hline $\mathrm{C}$ & $\mathrm{C} 1$ & 0,37 & 0,02 & 0,41 & 100 & 1 & 1 & 0 & 100 \\
\hline
\end{tabular}


Mahmud ImRona et. AL.

Penerapan Metode AHP...

\begin{tabular}{|c|c|c|c|c|c|c|c|c|c|}
\hline $\begin{array}{l}\text { Uji } \\
\text { Kasus }\end{array}$ & $\begin{array}{c}\text { Ruas Jalan } \\
\text { (Region) }\end{array}$ & $B_{I}$ & $C_{I}$ & $A_{I}$ & $\begin{array}{c}U_{I} \\
(\%)\end{array}$ & $\begin{array}{c}\text { Prioritas COPRAS-G } \\
(f i)\end{array}$ & $\begin{array}{c}\text { Prioritas PKK PJN } \\
(y i)\end{array}$ & $\begin{array}{l}\text { MAE } \\
(\%)\end{array}$ & $\begin{array}{c}\text { Akurasi } \\
(\%)\end{array}$ \\
\hline & $\mathrm{C} 2$ & 0,21 & 0,03 & 0,24 & $\begin{array}{l}57,94 \\
\end{array}$ & 3 & 3 & & \\
\hline & C3 & 0,32 & 0,04 & 0,35 & 83,49 & 2 & 2 & & \\
\hline \multirow{4}{*}{ D } & D1 & 0,15 & 0,02 & 0,18 & 44,36 & 3 & 3 & \multirow{4}{*}{0} & \multirow{4}{*}{100} \\
\hline & D2 & 0,14 & 0,01 & 0,17 & 42,97 & 4 & 4 & & \\
\hline & D3 & 0,24 & 0,03 & 0,26 & 65,96 & 2 & 2 & & \\
\hline & D4 & 0,38 & 0,03 & 0,39 & 100 & 1 & 1 & & \\
\hline \multirow{4}{*}{ E } & E1 & 0,29 & 0,03 & 0,30 & 81.93 & 2 & 2 & \multirow{4}{*}{0} & \multirow{4}{*}{100} \\
\hline & E2 & 0,16 & 0,01 & 0,20 & 53,10 & 3 & 3 & & \\
\hline & E3 & 0,13 & 0,04 & 0,14 & 37,84 & 4 & 4 & & \\
\hline & E4 & 0,33 & 0,01 & 0,37 & 100 & 1 & 1 & & \\
\hline \multirow{5}{*}{$\mathrm{F}$} & F1 & 0,09 & 0,03 & 0,10 & 32,09 & 5 & 5 & \multirow{5}{*}{0} & \multirow{5}{*}{100} \\
\hline & $\mathrm{F} 2$ & 0,29 & 0,02 & 0,31 & 100 & 1 & 1 & & \\
\hline & F3 & 0,16 & 0,01 & 0,19 & 61,62 & 3 & 3 & & \\
\hline & $\mathrm{F} 4$ & 0,10 & 0,01 & 0,13 & 43,30 & 4 & 4 & & \\
\hline & F5 & 0,27 & 0,03 & 0,28 & 90,16 & 2 & 2 & & \\
\hline \multirow{5}{*}{ G } & G1 & 0,13 & 0,01 & 0,16 & 49.71 & 4 & 4 & \multirow{5}{*}{0} & \multirow{5}{*}{100} \\
\hline & G2 & 0,16 & 0,02 & 0,18 & 53,70 & 3 & 3 & & \\
\hline & G3 & 0,31 & 0,02 & 0,33 & 100 & 1 & 1 & & \\
\hline & G4 & 0,23 & 0,02 & 0,24 & 75,03 & 2 & 2 & & \\
\hline & G5 & 0,07 & 0,02 & 0,09 & 28,04 & 5 & 5 & & \\
\hline \multirow{10}{*}{$\mathrm{H}$} & $\mathrm{H} 1$ & 0,05 & 0,01 & 0,05 & 33,17 & 9 & 9 & \multirow{10}{*}{0} & \multirow{10}{*}{100} \\
\hline & $\mathrm{H} 2$ & 0,11 & 0,00 & 0,12 & 79,72 & 4 & 4 & & \\
\hline & $\mathrm{H} 3$ & 0,08 & 0,02 & 0.08 & 54,79 & 7 & 7 & & \\
\hline & $\mathrm{H} 4$ & 0,15 & 0,01 & 0,15 & 100 & 1 & 1 & & \\
\hline & H5 & 0,06 & 0,01 & 0,07 & 45,34 & 8 & 8 & & \\
\hline & H6 & 0,02 & 0,00 & 0,04 & 24,62 & 10 & 10 & & \\
\hline & $\mathrm{H} 7$ & 0,08 & 0,01 & 0,09 & 61,11 & 6 & 6 & & \\
\hline & $\mathrm{H} 8$ & 0,13 & 0,00 & 0,15 & 97,94 & 2 & 2 & & \\
\hline & H9 & 0,12 & 0,01 & 0,12 & 80,97 & 3 & 3 & & \\
\hline & H10 & 0,11 & 0,02 & 0,11 & 73,01 & 5 & 5 & & \\
\hline \multirow{10}{*}{ I } & I1 & 0,05 & 0,02 & 0,06 & 30,35 & 9 & 9 & \multirow{10}{*}{0} & \multirow{10}{*}{100} \\
\hline & $\mathrm{I} 2$ & 0,07 & 0,01 & 0,08 & 41,15 & 6 & 6 & & \\
\hline & I3 & 0,15 & 0,01 & 0,16 & 88,21 & 2 & 2 & & \\
\hline & I4 & 0,12 & 0,01 & 0,13 & 71,60 & 3 & 3 & & \\
\hline & I5 & 0,18 & 0,02 & 0,18 & 100 & 1 & 1 & & \\
\hline & I6 & 0,09 & 0,00 & 0,10 & 55,21 & 5 & 5 & & \\
\hline & I7 & 0,07 & 0,01 & 0,07 & 40,34 & 7 & 7 & & \\
\hline & I8 & 0,10 & 0,01 & 0,11 & 57,76 & 4 & 4 & & \\
\hline & I9 & 0,03 & 0,01 & 0,04 & 23,00 & 10 & 10 & & \\
\hline & I10 & 0,06 & 0,01 & 0,07 & 38,47 & 8 & 8 & & \\
\hline
\end{tabular}

Keterangan :

Bi : Jumlah dari kriteria yang lebih Besar

$\mathrm{Ci}$ : Jumlah dari kriteria yang lebih kecil

Ai : Nilai signifikansi relatif dari setiap alternatif

Ui : Nilai derajat utilitas dari setiap alternatif

Pada Table 6 menunjukan hasil penentuan prioritas perbaikan drainase yang didapatkan dari perhitungan COPRAS-G yang sudah di urutkan berdasarkan nilai Ui. Pada kasus uji A urutan prioritas yang pertama adalah ruas jalan A3 dengan nilai Ui sebesar 100\%, urutan kedua ruas jalan A2 dengan nilai Ui sebesar 72,76\% dan 
urutan ke 3 ruas jalan A1 dengan nilai Ui sebesar 38,60. Kemudian hitung nilai MAE dan nilai akurasi dari urutan prioritas COPRAS-G dan urutan prioritas dari PPK PJN Metropolitan Bandung pada kasus uji A. Didapatkan nilai MAE sebesar 0\% dan nilai akurasi sebesar $100 \%$ untuk kasus uji A. Pada seluruh kasus uji didapatkan nilai MAE sebesar $0 \%$ dan nilai akurasi sebesar $100 \%$.

\section{KESIMPULAN}

Berdasarkan hasil pengujian dan analisis maka dapat ditarik kesimpulan sebagai berikut :

1. Diperoleh bobot kepentingan setiap kriteria yaitu tingkat kerusakan dengan bobot 0,71 , volume kerusakan dengan bobot 0.20 dan waktu perbaikan dengan bobot 0,09 . Dengan nilai CR menunjukan bahwa penilaian bobot antara kriteria bersifat konsisten.

2. Dari pengujian dapat dilihat urutan prioritas perbaikan drainase dengan mengurutkan nilai Ui dari yang terbesar ke yang terkecil. Maka pada kasus uji A didapatkan urutan prioritas yang pertama adalah ruas jalan A3 dengan nilai Ui sebesar 100\%, urutan kedua ruas jalan A2 dengan nilai Ui sebesar 72,76\% dan urutan ke 3 ruas jalan A1 dengan nilai Ui sebesar 38,60. Dan pada semua kasus uji mendapatkan urutan prioritas COPRAS-G.

3. Dari 9 data set kerusakan drainase pada jalan soekarno-hatta di kota Bandung, urutan prioritas yang dihasilkan oleh COPRAS-G sama dengan urutan prioritas dari PPK PJN Metropolitan Bandung. Dengan nilai MAE sebesar 0\% dan nilai akurasi sebesar 100\% untuk setiap kasus uji.

\section{ACKNOWLEDGMENT}

Alhamdulillah, segala puji dan syukur kepada Allah Subhaanahu wa Ta'aalaa atas segala nikmat dan karunia-Nya, yang telah memberikan kemudahan bagi penulis untuk dapat menyelesaikan penelitian ini dengan judul "Penerapan Metode AHP dan COPRAS-G untuk Menentukan Prioritas Perbaikan Drainase Pada Jalan Nasional Di Kota Bandung". Penulis ingin mengucapkan terima kasih kepada ibu saya yang selalu memberikan saya semangat dan kekuatan untuk saya, dan juga kepada (alm) Bapak yang selalu menjadi panutan saya. Terima kasih kepada Pak Mahmud Imrona, Pak Eko Darwiyanto dan Ibu Dini Handayani yang telah membimbinga saya dalam mengerjakan penelitian ini. Dan terima kasih kepada PPK PJN Metropolitan Bandung yang telah mengizinkan saya melakukan penelitian ini.

\section{REFERENCES}

[1] S. H. Zolfani, N. Rezaeiniya, E. K. Zavadskas and Z. Turkis, "Forest Roads Location Based on AHP and COPRAS-G Method : An Empirical Study Based on Iran," E + M Ekonomie a Management, 2011.

[2] Mentri Pekerjaan Umum Republik Indonesia, "Peraturan Mentri Pekerjaan Umum Nomor : 13 /PRT/M/2011 Tentang Tata Cara Pemeliharaan dan Penilikan Jalan," 04 Oktober 2011. [Online]. Available: birohukum.pu.go.id/uploads/DPU/2011/PermenPU132011.pdf. [Accessed 10 Oktober 2017].

[3] Mentri Pekerjaan Umum Republik Indonesia, "Lampiran III Peraturan Mentri Pekerjaan Umum NOMOR 12/PRT/M/2014 Tentang $\begin{array}{lllll}\text { Penyelenggaraan Sistem } & \text { Drainase Perkotan," } 26 & \text { September } 2014 . & \text { [Online]. Available: }\end{array}$ http://birohukum.pu.go.id/uploads/DPU/2014/Lamp3-PermenPU12-2014.pdf. [Accessed 10 Oktober 2017].

[4] T. L. Saaty, "Decision making with the analytic hierarchy process," Int. J. Services Sciences, vol. 1, no. 1, 2008.

[5] Y. O. Ouma and R. Tateichi, "Urban Flood Vulnerability and Risk Mapping Using Integrated Multi-Parametric AHP and GIS : Methodological Overview and Case Study Assessment," Water, 2014.

[6] C. B. Madhuri, J. A. Chandulal and M. Padjma, "Selection of Best Web Site by Applying COPRAS-G method," International Journal of Computer Science and Information Technology, vol. 1, pp. 135-46, 2010.

[7] E. Mu and M. Pereyra-Rojas, "Practical Decision Making," in An Introduction to the Analytic Hierarchy Process (AHP) Using Super Decisions V2, Springer International Publishing, 2017, pp. 7-15.

[8] E. K. Zavadskas, A. Kaklauksas, Z. Turskis and J. Tamosaitiene, " Selection of the effective dwelling house," Journal of Civil Engineering and, vol. 14, no. 2, pp. 85-93, 2008.

[9] J. L. Deng, " Control problems of grey system, Systems and Control Letters," vol. 1, pp. 288-294, 1982.

[10] E. K. ZAVADSKAS, A. KAKLAUSKAS, Z. TURSKIS and J. TAMOŠAITIENE, "Multi-Attribute Decision-Making Model by Applying Grey Numbers," INFORMATICA, vol. 20, no. 2, pp. 305-320, 2009.

[11] K. Matsuda and C. J. Willmott, "Advantages of the mean absolute error (MAE) over the root mean square error (RMSE) in assessing average model performance," CLIMATE RESEARCH, vol. 30, pp. 79-82, 2005. 
